\title{
A dietary assessment of colonial Cape Town's enslaved population
}

\author{
Linda Mbeki $^{1,2,3}$ (D) Lisette M. Kootker ${ }^{3,4}$ (D) Jason E. Laffoon ${ }^{4,5}$ (D) Gareth R. Davies $^{4}$ (D) $\cdot$ Henk Kars $^{3}$ (D)
}

Received: 19 May 2020 / Accepted: 17 December 2020 / Published online: 7 January 2021

(C) The Author(s) 2021

\begin{abstract}
There is a growing body of bioarchaeological research on eighteenth and nineteenth century colonial Cape Town, a significant node in the transportation networks of both the Indian and Atlantic oceanic slave trades, attempting to shed light on the lives of enslaved persons. Here, a preliminary archaeological isotopic dietary baseline for the colonial Cape is presented. It is apparent from the data that cattle tended to graze far inland from Cape Town in an arid $\mathrm{C}_{3}-\mathrm{C}_{4}$ to purely $\mathrm{C}_{4}$ biome. Sheep/goats grazed close to the settlement or some distance away in $\mathrm{C}_{3}$ to $\mathrm{C}_{3}-\mathrm{C}_{4}$ biomes. A qualitative comparison of the baseline data to that of enslaved persons at The Cape suggests that this population did not consume large amounts of marine protein as has been concluded in the past. The archaeological baseline data was utilised, in combination with published modern data, to create a quantitative dietary reconstruction of a subset of this population using a Bayesian multi-source diet mixing model (FRUITS). The reconstruction confirms that the Cape's enslaved did not consume much marine protein but relied predominantly on terrestrial $\mathrm{C}_{3}$ plant protein.
\end{abstract}

Keywords Dietary assessment · Cape colonial diet · Enslaved persons · Dutch East India Company $\cdot$ FRUITS

\section{Introduction}

Colonial Cape Town was a significant node in both the Indian and Atlantic oceanic slave trades from the seventeenth to nineteenth century AD. A significant body of historical work exists for this period (Armstrong 1979; De Kock 1950; Groenewald 2010; Ross 1983; Worden 1985); however, it remains difficult to fully explore individual life histories. This is due in part to the nature of the archives available for enquiry in which enslaved persons are only mentioned in

This paper is dedicated to the memory of Professor Hendrik Kars (1950 2020)

Linda Mbeki

lmbeki@iziko.org.za

1 Iziko Museums of South Africa, 25 Queen Victoria Street, Cape Town 8001, South Africa

2 Department of Anatomy, University of Pretoria, Private Bag X323, Gezina, Pretoria 0031, South Africa

3 CLUE+, Vrije Universiteit Amsterdam, De Boelelaan 1105, 1081 HV Amsterdam, The Netherlands

4 Geology \& Geochemistry Cluster, Vrije Universiteit Amsterdam, De Boelelaan 1085, 1081 HV Amsterdam, The Netherlands

5 Faculty of Archaeology, Leiden University, Einsteinweg 2, 2333 CC Leiden, The Netherlands passing, the lack of material culture that can be associated with enslaved persons' spaces, and the lack of narratives written by the enslaved and formerly enslaved to describe their experiences.

Due to these limitations, archaeologists have increasingly looked to the skeletal archive to fill in the gaps in knowledge. Using a treble-isotope approach, it was determined that the enslaved individuals from the Pacquet Real, which was wrecked off the coast of Cape Town in 1818, came from diverse geographical origins based on a wide range of strontium isotope ratios and carbon and nitrogen isotope values (Cox 1996; Cox and Sealy 1997). A similar approach has been applied to two other significant skeletal collections at the Cape. Cox et al. (2001) used changes in $\delta^{13} \mathrm{C}$ and $\delta^{15} \mathrm{~N}$ values of different skeletal elements of the Cobern Street individuals (AD 1750-1827) to recreate life histories. Building on this study, Kootker et al. (2016a) employed a dual ${ }^{87} \mathrm{Sr} /{ }^{86} \mathrm{Sr}-\delta^{13} \mathrm{C}$ isotopic approach in conjunction with the presence of cultural markers to identify migration events experienced by enslaved persons. Although these studies used the carbon and nitrogen isotope systems as proxies for palaeodiet and palaeomobility (Cox et al. 2001; Kootker et al. 2016a), there are to date no comprehensive reference carbon and nitrogen isotope baseline data for the colonial Cape. Mbeki et al. (2017) combined osteological data with stable and radiogenic isotope systems to identify first-generation migrants to Cape Town in a changing social landscape and to further contextualise the V\&A 
Marina Residence archaeological site (AD 1750-1850). In addition to the research carried out on Indian Ocean trade networks, similar research has been carried out on enslaved individuals traded in the Atlantic Ocean world (Bastos et al. 2016; Goodman et al. 2009; Laffoon et al. 2018; Laffoon et al. 2012b; Nystrom et al. 2011; Schroeder et al. 2009, 2014).

Isotopic ratios can be measured precisely and accurately; however, the interpretation of the data and the correctness of geographic provenancing or palaeodietary assessment are strongly dependent on the presence of background isotope data and the accuracy thereof. For the Sr isotope system, several isotopic landscape maps, or isoscapes, have been published that give a first impression of which $\mathrm{Sr}$ isotope ratios are present in either the archaeological or modern environment (e.g. Bataille et al. 2018; Copeland et al. 2016; Hodell et al. 2004; Kootker et al. 2016b; Laffoon et al. 2012a). These predictive models can aid in narrowing the possible geographic regions of origin in archaeological, historical and forensic contexts. Although some Cape-focussed studies exclusively used the carbon and nitrogen isotope systems as proxies for diet and mobility, there are to date no comprehensive reference carbon and nitrogen isotope baseline data for the colonial Cape, essential for an accurate assessment of palaeodiet, and in specific cases, of palaeomobility.

This paper presents a preliminary archaeological faunal carbon and nitrogen isotope baseline dataset representative of the Cape colonial diet (circa late seventeenth century-mid eighteenth century) which can provide the basis for future research. The faunal remains analysed to generate this dataset were excavated at the Castle of Good Hope in central Cape Town (Fig. 1). Although these remains were determined not to have been situated in their primary context, they are indicative of the animal protein sources available at the colonial Cape. Further insights are gleaned from a qualitative comparison between these faunal data and isotopic information gathered from individuals found at the Cobern Street and Marina Residence burial grounds who were determined to have been enslaved persons from the eighteenth and nineteenth century. The Cobern Street individuals were buried with care and with burial goods although some of them had not been at the Cape for long, suggesting that they were quickly assimilated into a community of marginalised people. In stark contrast, the Marina Residence individuals were haphazardly buried and some exhibited evidence of medical procedures suggesting that they perhaps had fallen victim to one of the many epidemics colonial Cape Town was prone to or had succumbed to the diseases of seafaring, such as scurvy, whilst recovering in hospital. A quantitative dietary reconstruction was performed using the Food Reconstruction Using Transferred Signals (FRUITS) mixing model for a subset of the Cobern Street population using previously published collagen carbon and nitrogen isotope data (Cox et al. 2001) and newly generated dental enamel carbon isotope data $\left(\delta^{13} \mathrm{C}_{\text {carbonate }}\right)$. Hence, this paper provides direct estimations of the individual diets of enslaved persons at the colonial Cape for the first time.

\section{Archaeological setting}

The Castle of Good Hope, the oldest surviving colonial building in South Africa, was built between AD 1666 and 1679 as a five-pointed "star fort" during a time when the early Dutch settlement was vulnerable to attack by European powers with competing mercantile interests. This pentagonal structure surrounded by a moat was a microcosm of the colonial society that developed at The Cape, housing the settlement's highest-

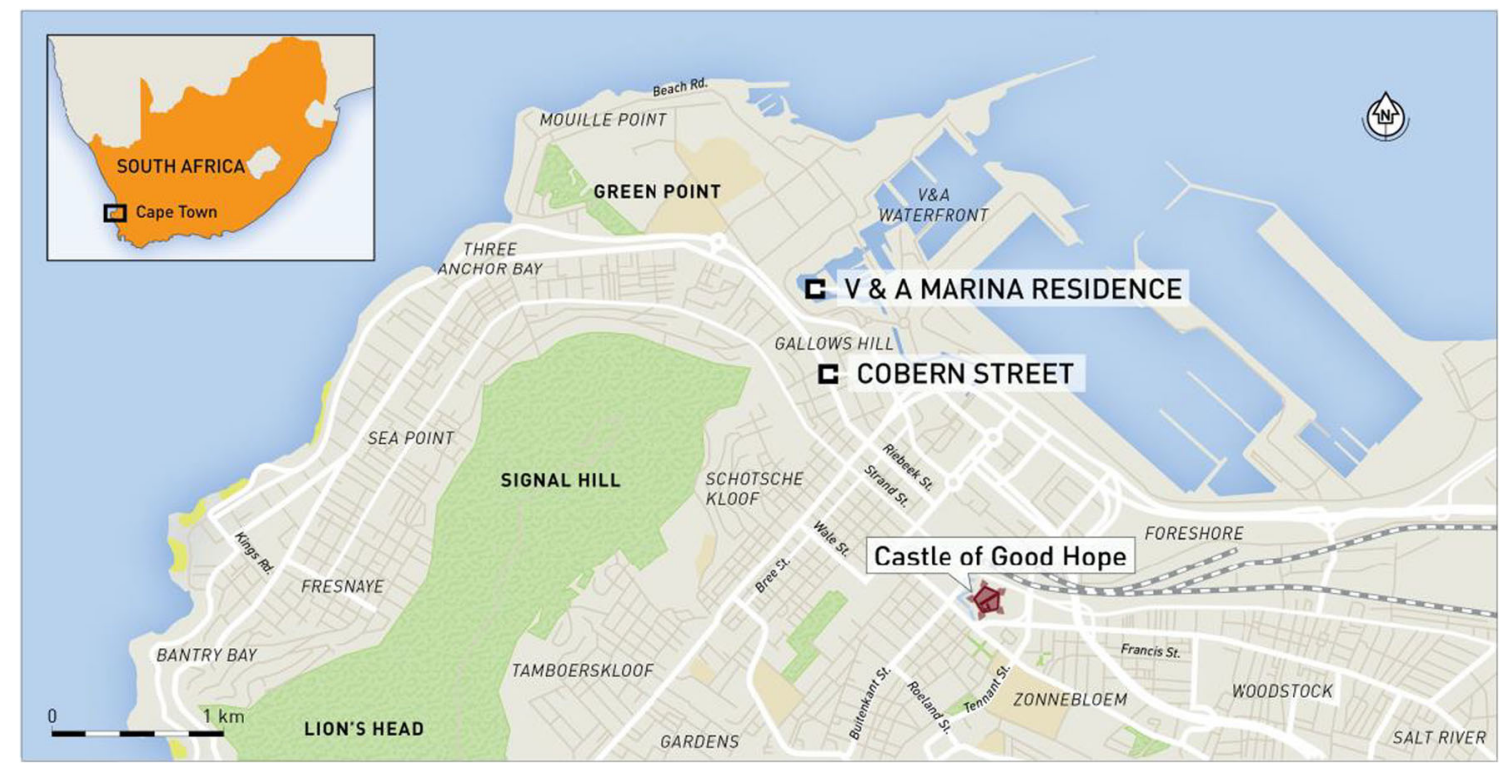

Fig. 1 Map of Cape Town, South Africa, with historical sites of interest to this study marked 
ranking Dutch East India Company (VOC) official, the governor, as well as lowly soldiers and sailors. A granary, prison cells and a church were also found within its walls. Several modifications have been identified from archaeological excavations and from the VOC's extensive written record. For instance, the moat was partially filled with garbage in the eighteenth century (Unknown 1996). Periodic flooding in the Castle due to the high water table was a constant worry during both the Dutch and British periods and resulted in raising of floor levels with cultural material-containing fill (Halkett 1991; Heinrich 2010; Unknown 1999a,b).

\section{Archaeozoological aspects of Cape diet}

In order to create a meaningful archaeological dietary isotope baseline for the enslaved of the colonial Cape, it is necessary to understand contemporaneous animal husbandry practises. A major contribution to the current understanding of the meat industry and diet at the colonial Cape has been made by Heinrich (2010). The essential findings of his zooarchaeological study from three assemblages from the Castle of Good Hope are presented below. Although no faunal remains have been found in a primary context that can conclusively be associated with the Cape's enslaved, urban assemblages from several secondary contexts illustrate the range of foods available for consumption at the colonial Cape.

Heinrich (2010) explains that from the establishment of the settlement at the Cape in the mid-eighteenth century, the colonists relied heavily on mutton for their own consumption and provisioning of passing ships as the indigenous Khoikhoi were reluctant to trade their cattle, which represented both economic and social capital. Company employees released from service, known as vrijburghers, could win contracts to supply the Dutch East India Company with meat (mainly mutton and beef). Through breeding, trade and theft from the Khoi, the vrijburghers' herds grew. Sheep consistently outnumbered cattle by several multiples during the Dutch period. Breeding of imported exotic cattle breeds was unsuccessful and the colony was to remain dependent on the indigenous variety, which was considered to be of poor quality, for draught and meat.

Heinrich (2010) indicates that pork was also consumed at the Cape, as is evident from faunal remains at the Castle from the colonial period, but not in great quantities. Exotic rabbits were introduced to the colony which already had indigenous rabbits. Chicken, geese, ducks and other domestic fowl were also introduced to the Cape by the VOC. Game, including wild birds such as penguin and ostrich, were hunted by low ranking VOC employees, particularly when food was scarce. In addition to the fresh meat supply, salt-cured meats were imported from Europe to the Cape. Also, wild game caught at VOC outposts would often be salted before transportation back to Cape Town, as would ocean-caught fish.
Based on archaeozoological findings, Markell et al. (1995) have concluded that enslaved persons were heavily reliant on fish as a source of protein. Andrén (1998) has written about Martin Hall's work and the discrepancy between the written and archaeological records. The former contains numerous accounts of fish shortages and the latter suggests an abundance of the foodstuff at the Cape. Andrén ultimately states that "fish was thus associated with slaves" (1998:174). In time, when the beef and mutton supply became more stable, many types of fish would be looked down upon as low class or slave food (Heinrich 2010). This limited variety of foodstuffs and the influence of Eastern enslaved persons in an African context gave birth to the creole Cape Malay cuisine that includes curries and pickled fish (Baderoon 2007). Socioeconomic factors trumped religious law when it came to a debate over the consumption of crayfish by Cape Muslims in the nineteenth century. One school of Islamic thought categorised this shellfish as carrion and thus haraam (unlawful/forbidden); however, as former enslaved persons and part of the urban poor, Cape Muslims relied heavily on crayfish and fish such as snoek [Thyrsites atun] (ibid). To this day "snoek is an important source of readily available and affordable protein to many medium- and low-income households" in the west-coast region of South Africa (Henning and Hoffman 2017:1).

The importance of affordable marine resources to the urban poor diet is also illustrated in older texts. The small Chinese community at the Cape was described by Mentzel in the late eighteenth century as "expert fishermen as well as good cooks" who ran eateries. He goes on to state that "fried or pickled fish with boiled rice is well-favoured by soldiers, sailors and slaves. When the fierce North-Westers blow, crayfish, crabs, seaspiders and 'granelen' [small crabs] are cast ashore. They are jealously collected by these Orientals, cooked and sold" (in Armstrong 2012:114). Despite the general perception by researchers that Cape Town's enslaved population consumed vast amounts of fish, there has not been any quantitative research to confirm the assumption.

\section{Human isotopic dietary assessment}

The stable isotopes of carbon and nitrogen are the preferred systems for palaeodietary assessment. The ratio ${ }^{15} \mathrm{~N} /{ }^{14} \mathrm{~N}$ $\left(\delta^{15} \mathrm{~N}\right)$ identifies a consumer's trophic level that is on average 3-6\% greater than its diet, allowing for a distinction to be made between herbivores, omnivores and carnivores (Hedges and Reynard 2007; Kelly 2000; O'Connell et al., 2012; Schoeninger and Moore 1992). Marine ecosystems display relatively high $\delta^{15} \mathrm{~N}$ values as the base of the food chain is enriched in ${ }^{15} \mathrm{~N}$ compared with its terrestrial analogue due to a difference in nitrogen source (dissolved nitrates vs. atmospheric/soil nitrogen, see Schoeninger and DeNiro, 1984). Moreover, the marine food chain has more trophic 
levels, also resulting in elevated $\delta^{15} \mathrm{~N}$ values (Lee-Thorp 2008; Schwarcz and Schoeninger 2011). Other trophic levelindependent factors may contribute to variation in $\delta^{15} \mathrm{~N}$ values such as nutritional and water stress and consumption of salted foods (e.g. Ambrose 1991; Ambrose and DeNiro 1986; Hobson et al. 1993; Preiser et al. 2014). These factors in particular would be important considerations when interpreting Cape enslaved individuals' isotopic values.

Differences in ${ }^{13} \mathrm{C} /{ }^{12} \mathrm{C}\left(\delta^{13} \mathrm{C}\right)$ are directly related to the manner in which plants metabolise atmospheric $\mathrm{CO}_{2}$. Plants are separated into three categories based on the photosynthetic pathway they use to fix $\mathrm{CO}_{2}$. The most significant of these are the Calvin $\left(\mathrm{C}_{3}\right)$ and Hatch and Slack $\left(\mathrm{C}_{4}\right)$ which use ribulose bisphosphate carboxylase/oxygenase (RuBisCO) and phosphoenolpyruvate carboxylase (PEP) enzymes, respectively, for the fixation of $\mathrm{CO}_{2}$ (Calvin and Benson 1948; Farquhar 1983; Hatch and Slack 1966; Marshall et al. 2008). As a result of these differences, $\mathrm{C}_{3}$ plants have lower $\delta^{13} \mathrm{C}$ values than $\mathrm{C}_{4}$ plants. Intermediate $\delta^{13} \mathrm{C}$ values are evident in marine plants as the $\mathrm{CO}_{2}$ in marine environments is derived from ${ }^{13} \mathrm{C}$ enriched dissolved bicarbonate $\left(\mathrm{HCO}_{3}{ }^{-}\right)$. These isotopic differences are systematically propagated up the food chain. Hence, due to the difference in type of vegetation between the Cape (predominantly $\mathrm{C}_{3}$ ) and, for instance, Mozambique (predominantly $\mathrm{C}_{4}$ ), carbon isotope values are an effective proxy for mobility between the two regions (Cox and Sealy 1997).

\section{Material and methods}

The faunal assemblage analysed for this study is an aggregate of animal bones excavated at the Castle of Good Hope (excavated between 1978 and 1992) and curated by Iziko Museums. Although this assemblage was not excavated in its primary context, we believe that it is representative of the protein sources available at the Cape during the colonial period. Thus, the isotopic values are applicable to the assessment of the Cape enslaved persons' diets.

A large variety of taxa were chosen to generate a broad baseline and to be as representative as possible of the colonial Cape diet; hence, 60 archaeological samples representing 23 species from three biological classes (mammalia, aves and pisces) were collected from the Castle of Good Hope (Table 1). To obtain the highest minimum number of individuals (MNI), the same skeletal element of the same symmetry was selected per species. Where this approach was not feasible, skeletal elements of the same species with different morphological features and/or metric dimensions were selected to avoid the selection of intra-individual elements.

Sheep and cattle were raised at outposts at the Cape and the animals were driven to town for slaughter for provisioning of ships and local consumption; thus, the assemblage is representative of the end of the meat production process. The mammals in the assemblage were excavated from a section of the Castle moat with deposits from the 1720s. The majority of the sheep were in their prime (1.5-6 years), while most cows were older than 4-5 years. The pigs in the assemblage varied in age from sub-adult to adult (Heinrich and Schrire 2011). All the birds in the assemblage were recovered from the granary and date from the late seventeenth century to the mid-eighteenth century. Only adult birds are represented; however, this may be a result of taphonomic processes (Heinrich 2010).

The complete Cobern Street burial collection is curated at the Department of Human Biology, University of Cape Town. The collection is available for academic research. All necessary permits were obtained, which complied with all relevant regulations. Permission for sampling and analysis was granted by Heritage Western Cape (Ref.: 130129TS09) and an export permit for samples was obtained from the South African Heritage Resource Agency (Ref.: 9/2/018/0206. Permit ID: 219). Dental enamel samples for $\delta^{13} C_{\text {enamel }}$ analysis were obtained simultaneously with the sample collection for strontium isotope analysis (see Kootker et al. 2016a for more information about the selection process).

\section{Preparation of samples}

\section{Fauna}

Following the selection of appropriate elements, a subsample was taken with a target weight of 5-10 g using a diamond cutoff wheel on a Dremel Rotary Tool and if needed a coping saw. The samples were transferred to the Vrije Universiteit Amsterdam. Here, the samples were carefully cleaned of adherent soil, crushed, and circa $300 \mathrm{mg}$ of small bone fragments roughly uniform in size was subsampled and transferred to polypropylene vials (Elkay). The specific collagen extraction protocol employed and analytical details for carbon and nitrogen isotope analysis are described elsewhere (Mbeki et al. 2017). Stable isotopes were measured using an elemental analyser (NC2500; ThermoQuest) coupled to a Delta Plus ThermoQuest Finnigan isotope ratio mass spectrometer at the Vrije Universiteit Amsterdam. For calibration, USGS 40 and USGS 41 were used. The reproducibility of the analyses determined by repeated analysis of an internal standard (Bovine liver, NIST 1577c) was within $0.08 \%$ oror $\delta^{15} \mathrm{~N}$ and $0.01 \%$ ofor $\delta^{13} \mathrm{C}(n=17)$. The $\delta^{13} \mathrm{C}$ values are reported relative to standard Vienna PeeDee Belemnite (VPDB) and the $\delta^{15} \mathrm{~N}$ data relative to standard Ambient Inhalable Reservoir (AIR).

\section{New human apatite data}

Circa $5 \mathrm{mg}$ of dental enamel powder was sampled using an acid-cleaned diamond-tipped burr, collected in glass 2-ml 
Table 1 Taxa selected from the Castle of Good Hope archaeological faunal assemblage for carbon and nitrogen isotope analysis

\begin{tabular}{|c|c|c|c|}
\hline Class & Common name & Taxon & $N$ \\
\hline \multirow[t]{7}{*}{ Mammalia } & Cat & Felis catus & 1 \\
\hline & Cattle & Bos taurus & 10 \\
\hline & Dog & Canis lupus familiaris & 4 \\
\hline & Hyena & Hyaenidae sp. & 1 \\
\hline & Pig & Sus domesticus & 3 \\
\hline & Rabbit & Oryctolagus cuniculus & 2 \\
\hline & Sheep/goat & Ovis aries/Capra hircus & 11 \\
\hline \multirow[t]{16}{*}{ Aves } & Bustard & Otididae & 1 \\
\hline & Cape cormorant & Phalacrocorax capensis & 1 \\
\hline & Cape francolin & Pternistis capensis & 2 \\
\hline & Cape teal & Anas capensis & 2 \\
\hline & Chicken & Gallus Gallus domesticus & 4 \\
\hline & Common greenshank & Tringa nebularia & 2 \\
\hline & Crow & Corvus sp. & 1 \\
\hline & Domestic duck & Anas platyrhynchos domesticus & 2 \\
\hline & Francolin & Phasianidae & 2 \\
\hline & Goose & Anser sp. & 2 \\
\hline & Penguin & Spheniscidae & 1 \\
\hline & Pigeon & Columba sp. & 2 \\
\hline & Raven & Corvus corax & 2 \\
\hline & Turkey & Meleagris gallopavo & 2 \\
\hline & White breasted cormorant & Phalacrocorax lucidus & 1 \\
\hline & & & 27 \\
\hline Pisces & Sea breams/porgies & Sparidae & 1 \\
\hline
\end{tabular}

vials and transferred to the Vrije Universiteit Amsterdam. Here, circa $0.3 \mathrm{mg}$ of dental enamel was subsampled for $\delta^{13} \mathrm{C}_{\text {enamel }}$ analysis. The isotope composition was analysed using a Thermo Finnigan GasBench II preparation device interfaced with a Thermo Finnigan Delta+ mass spectrometer. The measured isotope values are normalised to international standard IAEA-CO1 $\left(\delta^{13} \mathrm{C}=2.55 \pm 0.05,1 \sigma, n=11\right)$ and are reported relative to the Vienna Peedee Belemnite (VPDB) standard. The reproducibility during the four analytical sessions was on average $\pm 0.11 \%$ o $(1 \sigma)$.

\section{Multisource mixing model (FRUITS)}

One of the primary purposes of developing an isotopic baseline of the local and/or regional ecology is to interpret human stable isotope data from archaeological contexts. There has been an increasing trend in the application of mixing models for isotopic dietary reconstructions in recent years (Moore and Semmens 2008; Newsome et al. 2004; Parnell et al. 2010; Parnell et al. 2013; Phillips 2001; Phillips and Gregg 2003). In this study, a multisource mixing model (Food Reconstruction Using Isotopic Transferred Signals -
FRUITS) is applied to derive quantitative estimates of the relative contributions of different food groups to individual diets. Specifically, individual isotopic data were analysed with the Bayesian mixing model software FRUITS v2.1.1 (Fernandes et al. 2014). The FRUITS programme was considered ideal for this study owing to its capacity to incorporate macronutrient, elemental and isotopic data, in addition to the integration of associated uncertainties of both consumer and food source. The model utilised four food sources: terrestrial animals, marine animals, $\mathrm{C}_{3}$ plants and $\mathrm{C}_{4}$ plants. The model setup and input parameters are reported elsewhere (Pestle and Laffoon 2018).

Food source isotope data includes the new faunal collagen carbon and nitrogen isotope data presented in this study, combined with a compilation of both archaeological and modern animal and plant isotope data sets gathered from relevant literature ( $n=1012$, see Supplementary Data for a complete overview of the reference data). To increase the amount of fish data, modern anchovy (Engraulis capensis, $n=12$ ) and round herring (Etrumeus whiteheadi, $n=5$ ) collagen data (Sholto-Douglas et al. 1991) and hake (Merluccius capensis, $n=201$, and Merluccius paradoxus, $n=180$ ) dorsal muscle 
isotope data (provided by C. van der Lingen) are included in this study. Stable isotope data from modern samples were corrected by $+1.5 \%$ o (terrestrial) and $+3.0 \%$ (marine) to $\delta^{13} \mathrm{C}$ values to account for the Suess effect (Keeling et al. 1979; Marino and McElroy 1991; Pestle 2010).

Human carbon and nitrogen isotope data from Cape Town's Cobern Street collection was used (Cox et al. 2001). Out of the 53 analysed individuals, 13 were selected for input into the FRUITS model. The sampling strategy for this aspect of the study focuses on individuals believed to have originated from the Cape and surrounding area (i.e. locals). Locals (burial numbers 18, 23, 32, 42A, 47 and 61) were identified either by local ${ }^{87} \mathrm{Sr} /{ }^{86} \mathrm{Sr}$ values $(0.7086-0.7179)$, determined from human and faunal data and/or local $\delta^{13} \mathrm{C}_{\text {cancellous bone }}(-18.8 \%$ to $-13.5 \%$ o) (Cox et al. 2001; Kootker et al. 2016a). Non-local individuals (burial numbers $14,21,34,50,54,57$ and 58) were also analysed to determine the extent to which individual diets changed upon migration to the Cape. These individuals' childhood diets represent those of their place(s) of origin and thus do not reflect diet at the colonial Cape. Strontium isotope data have demonstrated the uncertainty of life for enslaved persons in the Indian Ocean world where migration of enslaved labour between different regions was prevalent. Determining whether and how diet varied between places of origin and the Cape demonstrates how enslaved persons were affected culturally by being uprooted from one society and implanted in another.

Human isotopic data were first converted to account for diet to tissue fractionation. The tissue-diet (apatite-whole diet) fractionation factor for $\delta^{13} \mathrm{C}_{\text {enamel }}$ (bioapatite) was stipulated as $10.1 \pm 0.4 \%$ (Fernandes et al. 2012). For $\delta^{15} \mathrm{~N}_{\text {collagen }}$, a trophic fractionation offset (collagen-protein) of $3.6 \pm 1.2 \%$ was applied, as reported in various controlled studies of omnivorous mammals (Ambrose 2002; DeNiro and Epstein 1981; Edgar Hare et al. 1991; Howland et al. 2003; Sponheimer et al. 2003; Warinner and Tuross 2009). The consumer-foodstuff offset and associated error for $\delta^{13} \mathrm{C}_{\text {collagen }}$ was determined using the linear regression $\left(\delta^{13} \mathrm{C}_{\text {protein }}(\%)=\left(0.78 \times \delta 13 \mathrm{C}_{\mathrm{co}}\right)-\left(0.58 \times \Delta^{13} \mathrm{C}_{\mathrm{ap}}-\mathrm{co}\right)-\right.$ 4.7) described in Pestle et al. (2015). Instrumental uncertainties of $0.1 \%$ were input into the model for all three measured stable isotope values.

Macronutrient composition for the four food sources was estimated based on the reported composition of similar foods in the USDA National Nutrient Database for Standard Reference (USDA 2013). Dry weights were calculated after subtraction of the water portion, fibre, and the protein and energy (fats plus carbohydrates) macronutrient composition for each food was determined. These values were then converted to a percentage and averaged to determine the mean and standard deviation for each food group. The elemental compositions of each food group were calculated based on the formulae in Morrison et al. (2000). The isotopic offsets between measured bulk food isotope values and the isotopic values of its constituent macronutrients were derived from Tieszen (1991). Relevant food source isotope data for both animals and plants was gathered from the published literature and can be found in Supplementary Data. Summary statistics of bulk food source and macronutrient isotope data are listed in Table 2.

In order to control for variations in the routing of different elements between diet and tissue, $100 \%$ of nitrogen in bone collagen was assumed to derive from dietary protein. Carbon in hydroxyapatite (bioapatite) was stipulated as reflecting an average of dietary carbon from all three macronutrient sources, and the carbon composition of bone collagen was estimated to represent approximately $74 \% \pm 4 \%$ dietary protein and $26 \% \pm 4 \%$ energy (Fernandes et al. 2012). A minimum $(10 \%)$ and maximum $(45 \%)$ of protein intake were input into the FRUITS prior data option to account for the lower and upper limit of possible human protein consumption (WHO 2007).

\section{Results and discussion}

\section{Quality indicator collagen}

Collagen quality was assessed using four indicators (collagen yield, weight $\% \mathrm{C}$, weight $\% \mathrm{~N}$ and atomic $\mathrm{C} / \mathrm{N}$ ) commonly employed by stable isotope and radiometric dating laboratories worldwide (Pestle and Colvard 2012; Pestle et al. 2014). Despite multiple attempts to extract collagen of reasonable quality, seven samples did not possess appreciable amounts of collagen $(<0.5 \mathrm{wt} \%)$. The remaining $53(88 \%)$ faunal collagen samples had more than the preferred lower threshold values of carbon $(>13.0 \mathrm{wt} \% \mathrm{C})$ and nitrogen $(>4.8 \mathrm{wt} \% \mathrm{~N}$ : (Ambrose 1990). Descriptive statistics of the data are presented in Table 3. Faunal wt $\% \mathrm{~N}$ and $\mathrm{wt} \% \mathrm{C}$ data are plotted against each other in Fig. 2. These quality indicators vary proportionally to one another and form a well-defined regression line $\left(R^{2}=0.9785\right)$. This suggests that the collagen from these samples retained its integrity and was not subject to attack by bacteria that target carbon-rich amino acids (Pestle and Colvard 2012).

\section{Faunal carbon and nitrogen isotopic data}

The collagen data for the 53 samples with acceptable quality indicators are presented in Table 4. Although some of the sample sizes representing the different taxa are small, some tentative conclusions can be made based on the isotopic data. Notably, cattle seem to have consumed a mixed $\mathrm{C}_{3} / \mathrm{C}_{4}$ to purely $\mathrm{C}_{4}$ diet; their $\delta^{15} \mathrm{~N}$ values range from 5.4 to $10.3 \%$. The highest values could be a reflection of grazing in an arid region and the associated water stress. In response to water 
Table 2 Adjusted isotope data for four food source groups. Protein and energy are given in percent $(\%) . \delta^{13} \mathrm{C}$ is reported in per mil (\%o) versus VPDB. $\delta^{15} \mathrm{~N}$ is reported in per mil (\%o) versus AIR. SD: standard deviation

\begin{tabular}{|c|c|c|c|c|c|c|c|c|c|c|c|c|c|c|c|c|c|}
\hline Food group & $N_{\text {total }}$ & Protein & SD & Energy & SD & $N_{\text {carbon }}$ & ${ }^{\delta} \mathrm{C}_{\text {bulk }}$ & SD & $N_{\text {nitrogen }}$ & $\begin{array}{l}\delta \\
{ }^{15} \mathrm{~N}_{\text {bulk }}\end{array}$ & SD & $\begin{array}{l}\delta \\
{ }^{13} \mathrm{C}_{\text {protein }}\end{array}$ & $\mathrm{SD}$ & $\begin{array}{l}\delta \\
{ }^{13} \mathrm{C}^{\text {energy }}\end{array}$ & SD & $\begin{array}{l}\delta \\
{ }^{15} \mathrm{~N}_{\text {protein }}\end{array}$ & SD \\
\hline Land animals & 96 & 58 & 25 & 42 & 25 & 96 & -16.9 & 4.9 & 50 & 9.4 & 2.4 & -10.4 & 4.9 & -22.9 & 4.9 & 9.4 & 2.4 \\
\hline Marine animals & 518 & 75 & 22 & 25 & 22 & 518 & -13.1 & 2.0 & 472 & 12.9 & 2.5 & -10.8 & 2.0 & -18.3 & 2.0 & 12.9 & 2.5 \\
\hline $\mathrm{C}_{3}$ vegetation & 356 & 18 & 14 & 82 & 14 & 346 & -25.5 & 1.8 & 344 & 1.4 & 3.5 & -26.0 & 1.8 & -25.4 & 1.8 & 1.4 & 3.5 \\
\hline $\mathrm{C}_{4}$ vegetation & 42 & 10 & 1 & 90 & 1 & 28 & -10.0 & 2.2 & 40 & 2.3 & 2.4 & -9.6 & 2.2 & -10.1 & 2.2 & 2.3 & 2.4 \\
\hline
\end{tabular}

stress, high-urea-content urine is passed by mammals. Due to fractionation, this urea is enriched in the lighter nitrogen isotope, ${ }^{14} \mathrm{~N}$, and the resulting nitrogen pool in the body is enriched in ${ }^{15} \mathrm{~N}$ (Ambrose 1991). Three sheep/goats in the assemblage display a purely $\mathrm{C}_{3}$ signal $\left(31,34,35: \delta^{13} \mathrm{C}<-\right.$ $18.3 \%$ o) consistent with grazing closer to Cape Town. The remaining four sheep $\left(30,36,37,38: \delta^{13} \mathrm{C}-11.0\right.$ to $16.0 \%$ o) display mixed $\mathrm{C}_{3} / \mathrm{C}_{4}$ values suggesting that they, like the cattle, grazed some distance from Cape Town.

As mentioned before, vrijburghers in the Cape province grew their herds by breeding, trade and theft from the indigenous Khoi. The two cattle exhibiting purely $\mathrm{C}_{4}$ dietary signals (54, 60: $\delta^{13} \mathrm{C}-8.8 \%$ and $-7.1 \%$, respectively) may have been supplied by the Khoi or they may illustrate the extent to which the Dutch colonists laid claim to vast tracts of land formerly used by the indigenous Khoi to graze their herds. This would have been in direct response to the demand for fresh meat for passing ships and the rapidly expanding settlement. Not only is intra-species isotopic variation evident for sheep/goats, it is also evident among animals that would be found in the domestic sphere. Two dogs consumed a purely $\mathrm{C}_{3} \operatorname{diet}\left(44,48: \delta^{13} \mathrm{C}-20.7 \%\right.$ and $-20.9 \%$, respectively) and plot among the domestic fowl. The other two dogs (45, 49) were omnivorous and consumed a mixed $\mathrm{C}_{3} / \mathrm{C}_{4} \operatorname{diet}\left(\delta^{13} \mathrm{C}\right.$ $-14.1 \%$ and $-14.4 \%$, respectively) with a possible marine protein contribution indicated by their high $\delta^{15} \mathrm{~N}(\sim 13 \%)$.

The two rabbits in the sample $(41,42)$, which one would expect to have consumed a terrestrial diet, display unusually elevated $\delta^{15} \mathrm{~N}$ (13.2\%o and $14.6 \%$, respectively). Perhaps they were hunted in an arid area, such as that on which the cattle were grazed. As rabbits engage in coprophagy and recycle at least $40 \%$ of their faeces, this could also result in elevated $\delta^{15} \mathrm{~N}$ values (Giovannetti 1982). Another unexpected feature of the dataset is that the hyena, a carnivore, plots in a similar region as the domestic fowl and pigs. The chickens, turkeys, domestic duck, geese and pigs, animals that are raised in domestic spaces, are also enriched in ${ }^{15} \mathrm{~N}$. The four chickens analysed all consumed a $\mathrm{C}_{3} \operatorname{diet}\left(\delta^{13} \mathrm{C}>17.3 \%\right.$ ) , but there was considerable variation in their $\delta^{15} \mathrm{~N}(7.6-12.0 \%$ ). The elevated ${ }^{15} \mathrm{~N}$ values of these animals may be the result of consuming plants grown on manured soil (Bogaard et al. 2007). Moreover, if these plants were close to the coast, they would also be subject to sea spray which would also result in elevated $\delta^{15} \mathrm{~N}$ values. Müldner et al. (2014) have suggested that Belgian herbivores with a $\delta^{15} \mathrm{~N}>9 \%$ o were subject to a coastal influence that incorporated sea spray, soil salinity and $\mathrm{pH}$ effects on the plants they ate. Increased soil salinity results in an increase in $\mathrm{pH}$ which in turn increases $\mathrm{NH}_{3}$ volatilisation and plant uptake of ${ }^{15} \mathrm{~N}$-enriched $\mathrm{NH}_{4}{ }^{+}$(Van Groenigen and Kessel 2002). These factors may also have been at play at the Cape.

To determine which protein sources were major contributors to the diet of enslaved persons at the Cape, the $\delta^{13} \mathrm{C}$ and $\delta^{15} \mathrm{~N}$ values of all fauna are plotted in Fig. 3 along with the mean isotope values for the Cobern Street (Cox et al. 2001) and Marina Residence (Mbeki et al. 2017) individuals. We assume that the individuals who were buried at these two sites are representative of the enslaved (privately and Companyowned) and formerly enslaved population at the Cape.

Surprisingly, marine fish, such as anchovy and round herring, were not a major source of protein for the enslaved of Cape Town at this point in time (AD 1750-1850). The one

Table 3 Descriptive statistics $(n=53) . \delta^{13} \mathrm{C}$ is reported in per mil $(\% o)$ versus VPDB. $\delta^{15} \mathrm{~N}$ is reported in per mil (\%o) versus AIR

\begin{tabular}{|c|c|c|c|c|c|c|}
\hline & Yield (\%) & $\delta^{15} \mathrm{~N}(\% \circ)$ & $\mathrm{wt} \% \mathrm{~N}$ & $\delta^{13} \mathrm{C}(\% o)$ & $\mathrm{wt} \% \mathrm{C}$ & Atomic $\mathrm{CN}$ ratio \\
\hline Average & 9.7 & 10.0 & 12.8 & -15.9 & 37 & 3.4 \\
\hline SD & 5.8 & 2.5 & 1.9 & 3.9 & 5.1 & 0.1 \\
\hline Min & 1.7 & 5.1 & 8.5 & -22.2 & 25 & 3.2 \\
\hline Max & 20.8 & 17.2 & 15.2 & -7.1 & 43.6 & 3.6 \\
\hline
\end{tabular}


Fig. 2 Faunal wt $\% \mathrm{~N}$ vs wt $\% \mathrm{C}$ showing $R^{2}=0.98(n=53)$

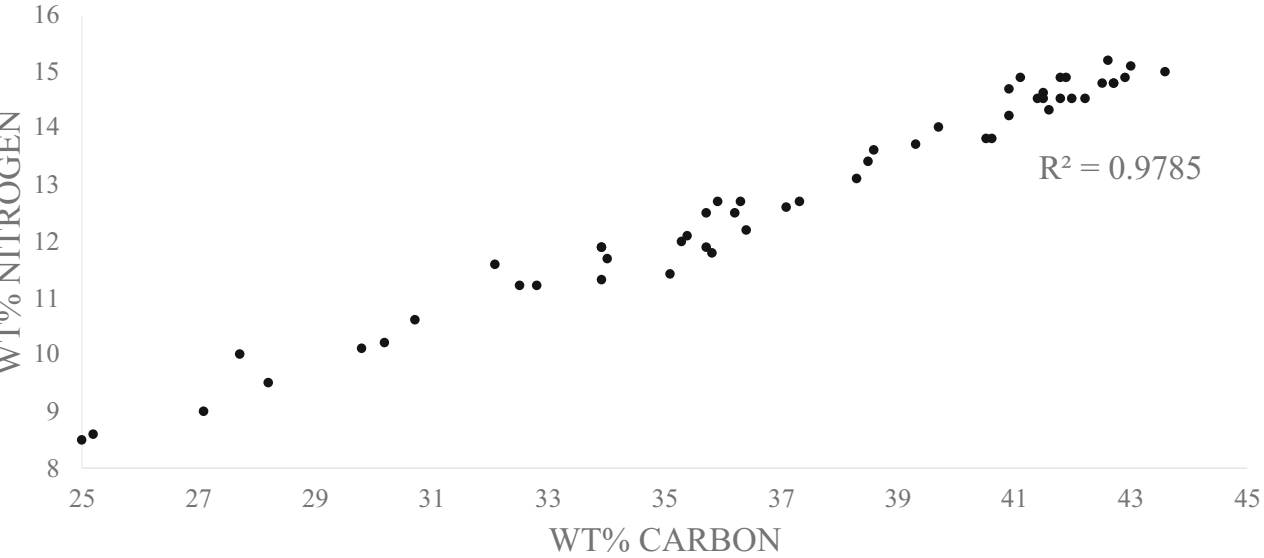

fish represented in the archaeological assemblage, sea bream, also does not appear to have contributed significantly to the diet of enslaved people. This is indeed perplexing, as we have outlined above, common wisdom amongst Cape historians and others (Andrén 1998; Baderoon 2007; Heinrich 2010; Moenieba 2013) is that marine fish was frequently consumed by enslaved persons. The results from the current research suggest that this population did not consume large quantities of the marine fish represented in this dataset. Inclusion of other types of marine fish, particularly snoek, and other marine resources such as molluscs and shellfish in the dataset may lead to firmer conclusions about the extent to which Cape Town's enslaved population exploited marine protein.

The Cobern Street individuals are a trophic level above the average sheep/goat $\left(\Delta^{15} N=3.3 \%\right.$ o, $\Delta^{13} C=0.2 \%$ o) suggesting that they could have consumed this protein source. The Marina Residence individuals are nearly two trophic levels above sheep/goats ( $\Delta^{15} N 5.6 \%$ ) suggesting factors other than a trophic effect are involved. Illness, consumption of more salt-preserved protein or consumption of higher trophic level marine resources have been suggested (Mbeki et al. 2017).

Beef does not appear to have been a significant part of the diet of either the Cobern Street or Marina Residence individuals. Again, the isotopic data are in contrast to the written sources in which Company enslaved persons' diet is recorded. The Company journal entry of September 27th, 1674 states: The wagon arrives from Hottentoos Holland with a cask of salted beef and mutton, the carcases of cattle and sheep that had been killed in consequence of their leanness and decaying strength. It will be distributed here as food for the slaves (Leibbrandt 1902):215). Company-owned enslaved diets may have included beef; however, the Cobern Street and Marina individuals, who may be representative of privately owned enslaved persons, did not eat it in significant quantities. The daily lives of privately owned enslaved persons were poorly documented, if at all, but it is apparent from the isotopic data that there may have been a significant difference in the diet of Company-owned persons relative to that of privately owned enslaved persons. Domestic and wild birds, and pork do not seem to have been consumed by the enslaved in significant quantities, and their presence in the faunal assemblage is most probably as a result of their consumption at the governors table as suggested by Heinrich (2010).

What this qualitative approach affords us is a general indication of the possible protein sources that were consumed by a population. We can neither gain insights into the proportions of different proteins consumed by individuals, nor the plant food contribution to diets. Despite the absence of comprehensive baseline data, Kootker et al. (2016a) placed significant constrains on the local isotopic dietary signature of the enslaved of Cape Town. The individual dietary reconstructions provided by FRUITS are the first attempts to fill this gap in knowledge.

\section{Quantitative dietary reconstruction with multisource mixing model (FRUITS)}

Human stable isotope data for 13 individuals from the Cobern Street burials at the colonial Cape of Good Hope are listed in Table 5. For this sample population, the human isotopic data are from dentine collagen and enamel hydroxyapatite (bioapatite). The collagen isotope data derive from the study by Cox et al. (2001) and the apatite isotope data represent the results of new analyses generated for the present study. The use of bioapatite carbon isotope values from dental enamel as a sampling material is preferable as it is generally considered highly resistant to post-mortem contamination (diagenesis), whereas bone bioapatite has been documented to be much more susceptible to diagenesis (e.g. Lee-Thorp and Sponheimer 2003). The enamel apatite carbon isotope values reflect an average of whole diet, while the dentine collagen isotope signal is dominated by the protein component of diet. The formation times of enamel and dentin (from the same dental element) are not identical, but both represent dietary intake during childhood (Nelson and Ash 2010). 
Table 4 Isotopic data from faunal remains from the Castle of Good Hope dating from the colonial period. Supplementary fish isotopic data from Sholto-Douglas et al. (1991). $\delta^{13} \mathrm{C}$ is reported in per mil (\%o) versus VPDB. $\delta^{15} \mathrm{~N}$ is reported in per mil (\%o) versus AIR

\begin{tabular}{|c|c|c|c|c|c|c|c|c|c|c|c|c|}
\hline $\begin{array}{l}\text { VU } \\
\text { ID }\end{array}$ & Class & Taxon & Common name & $\begin{array}{l}\% \\
\text { Yield }\end{array}$ & ${ }^{\delta} \mathrm{N}$ & $\begin{array}{l}\% \\
\mathrm{~N}\end{array}$ & $\delta{ }^{13} \mathrm{C}$ & $\% \mathrm{C}$ & $\begin{array}{l}\mathrm{CN} \\
\text { ratio }\end{array}$ & Element & Symmetry & $\begin{array}{l}\text { Find } \\
\text { number }\end{array}$ \\
\hline 21 & Aves & Anas capensis & Cape teal & 13.2 & 17.2 & 14.5 & -16.1 & 42.2 & 3.4 & Coracoid & Right & - \\
\hline 22 & Aves & Anas capensis & Cape teal & 5.1 & 8.9 & 11.8 & -14.9 & 35.8 & 3.6 & Coracoid & Right & - \\
\hline 3 & Aves & $\begin{array}{l}\text { Anas platyrhynchos } \\
\text { dom. }\end{array}$ & Domestic duck & 13.3 & 10.6 & 14.6 & -19.2 & 41.5 & 3.3 & Radius & - & - \\
\hline 13 & Aves & Anser sp. & Goose & 20.8 & 7.1 & 14.7 & -19.0 & 40.9 & 3.3 & Humerus & Right & - \\
\hline 14 & Aves & Anser sp. & Goose & - & 9.6 & 13.1 & -17.0 & 38.3 & 3.4 & Coracoid & Left & - \\
\hline 26 & Aves & Columba sp. & Pigeon & 13.4 & 10.4 & 14.3 & -20.3 & 41.6 & 3.4 & Humerus & Right & - \\
\hline 27 & Aves & Columba sp. & Pigeon & 16.3 & 9.7 & 11.2 & -19.8 & 32.5 & 3.4 & Humerus & Left & - \\
\hline 4 & Aves & Corvus corax & Raven & 12.9 & 10.7 & 14.2 & -17.3 & 40.9 & 3.4 & Coracoid & Left & - \\
\hline 1 & Aves & Corvus sp. & Crow & 19.8 & 8.4 & 15.1 & -17.9 & 43.0 & 3.3 & Ulna & Left & - \\
\hline 17 & Aves & $\begin{array}{r}\text { Gallus gallus } \\
\text { domesticus }\end{array}$ & Chicken & 9.9 & 7.6 & 14.0 & -18.9 & 39.7 & 3.3 & Tibia & Left & - \\
\hline 18 & Aves & $\begin{array}{r}\text { Gallus gallus } \\
\text { domesticus }\end{array}$ & Chicken & 16.9 & 12.0 & 14.8 & -17.3 & 42.5 & 3.3 & Tibia & Left & - \\
\hline 19 & Aves & $\begin{array}{r}\text { Gallus gallus } \\
\text { domesticus }\end{array}$ & Chicken & 13.3 & 9.5 & 15.0 & -18.8 & 43.6 & 3.4 & Tibia & Left & - \\
\hline 20 & Aves & $\begin{array}{r}\text { Gallus gallus } \\
\text { domesticus }\end{array}$ & Chicken & 13.8 & 11.6 & 14.5 & -18.5 & 41.8 & 3.4 & Tibia & Left & - \\
\hline 15 & Aves & Meleagris gallopavo & Turkey & 18.8 & 12.7 & 14.9 & -19.6 & 41.8 & 3.3 & Coracoid & Left & - \\
\hline 16 & Aves & Meleagris gallopavo & Turkey & 17.9 & 10.9 & 14.5 & -18.2 & 41.4 & 3.3 & Coracoid & Left & - \\
\hline 12 & Aves & Otididae & Bustard & 20.8 & 9.1 & 14.8 & -17.1 & 42.7 & 3.4 & Coracoid & Right & - \\
\hline 24 & Aves & $\begin{array}{l}\text { Phalacrocorax } \\
\text { capensis }\end{array}$ & Cape cormorant & 16.1 & 15.2 & 14.9 & -13.5 & 42.9 & 3.4 & Coracoid & Left & - \\
\hline 25 & Aves & $\begin{array}{l}\text { Phalacrocorax } \\
\text { lucidus }\end{array}$ & $\begin{array}{c}\text { White breasted } \\
\text { cormorant }\end{array}$ & 12.7 & 14.4 & 12.7 & -10.2 & 37.3 & 3.4 & Humerus & Left & - \\
\hline 10 & Aves & Phasianidae & Francolin & 14.2 & 6.7 & 14.5 & -21.0 & 42.0 & 3.4 & Coracoid & Right & - \\
\hline 11 & Aves & Phasianidae & Francolin & 16.1 & 5.1 & 14.8 & -22.2 & 42.7 & 3.4 & Coracoid & Left & - \\
\hline 8 & Aves & Pternistis capensis & Cape francolin & 11.3 & 10.8 & 13.8 & -20.7 & 40.6 & 3.4 & Tibia & Right & - \\
\hline 6 & Aves & Tringa nebularia & Common greenshank & 16.8 & 10.3 & 12.6 & -18.1 & 37.1 & 3.4 & Humerus & Right & - \\
\hline 7 & Aves & Tringa nebularia & Common greenshank & 11.4 & 12.1 & 13.8 & -20.6 & 40.5 & 3.4 & Humerus & Left & - \\
\hline 46 & Mammal & Bos taurus & Cattle & 11.6 & 8.9 & 11.6 & -9.9 & 32.1 & 3.2 & Calcaneum & Right & 39.4 .1 \\
\hline 52 & Mammal & Bos taurus & Cattle & 1.7 & 8.7 & 10.2 & -12.5 & 30.2 & 3.5 & Calcaneum & Left & P.4.34 \\
\hline 53 & Mammal & Bos taurus & Cattle & 3.1 & 10.3 & 8.6 & -9.7 & 25.2 & 3.4 & Calcaneum & Left & K15.4.13 \\
\hline 54 & Mammal & Bos taurus & Cattle & 2.8 & 6.5 & 9.0 & -8.8 & 27.1 & 3.5 & Metatarsus & - & 4.8 \\
\hline 55 & Mammal & Bos taurus & Cattle & 4.4 & 8.0 & 11.2 & -10.6 & 32.8 & 3.4 & Calcaneum & Left & 4.5 \\
\hline 56 & Mammal & Bos taurus & Cattle & 4.5 & 9.1 & 12.7 & -10.3 & 36.3 & 3.4 & Calcaneum & Right & 4.2 \\
\hline 57 & Mammal & Bos taurus & Cattle & 3.3 & 5.4 & 11.9 & -11.7 & 33.9 & 3.3 & Tibia & Left & 4.1 \\
\hline 58 & Mammal & Bos taurus & Cattle & 3.8 & 5.6 & 12.2 & -10.4 & 36.4 & 3.5 & Tibia & Left & P.4.27 \\
\hline 59 & Mammal & Bos taurus & Cattle & 2.3 & 8.1 & 10.1 & -13.0 & 29.8 & 3.4 & Metacarpus & - & 4.7 \\
\hline 60 & Mammal & Bos taurus & Cattle & 2.9 & 7.5 & 11.7 & -7.1 & 34.0 & 3.4 & Tibia & Left & 12.4 .4 \\
\hline 44 & Mammal & $\begin{array}{l}\text { Canis lupus } \\
\text { familiaris }\end{array}$ & Dog & 7.2 & 11.1 & 10.0 & -20.7 & 27.7 & 3.2 & Mandible & Right & - \\
\hline 45 & Mammal & $\begin{array}{l}\text { Canis lupus } \\
\text { familiaris }\end{array}$ & Dog & 3.8 & 12.6 & 12.1 & -14.1 & 35.4 & 3.4 & Mandible & Left & $\mathrm{J} 10.4 .2$ \\
\hline 48 & Mammal & $\begin{array}{l}\text { Canis lupus } \\
\text { familiaris }\end{array}$ & Dog & 3.4 & 10.9 & 11.3 & -20.9 & 33.9 & 3.5 & Mandible & Right & G12.4.8 \\
\hline 49 & Mammal & $\begin{array}{l}\text { Canis lupus } \\
\text { familiaris }\end{array}$ & Dog & 2.6 & 12.9 & 10.6 & -14.4 & 30.7 & 3.4 & Mandible & Left & $\mathrm{TBC}$ \\
\hline 47 & Mammal & Felis catus & Cat & 9.1 & 11.5 & 14.9 & -13.8 & 41.1 & 3.2 & Mandible & Left & 7.4 .12 \\
\hline 51 & Mammal & Hyaenidae sp. & Hyena & 4.2 & 12.2 & 8.5 & -16.5 & 25.0 & 3.4 & Maxilla & Right & 10.4 .1 \\
\hline 41 & Mammal & $\begin{array}{r}\text { Oryctolagus } \\
\text { cuniculus }\end{array}$ & Rabbit & 9.3 & 14.6 & 13.4 & -13.2 & 38.5 & 3.4 & Humerus & Left & P.4.69 \\
\hline
\end{tabular}


Table 4 (continued)

\begin{tabular}{|c|c|c|c|c|c|c|c|c|c|c|c|c|}
\hline $\begin{array}{l}\text { VU } \\
\text { ID }\end{array}$ & Class & Taxon & Common name & $\begin{array}{l}\% \\
\text { Yield }\end{array}$ & ${ }^{15} \mathrm{~N}$ & $\begin{array}{l}\% \\
\mathrm{~N}\end{array}$ & $\delta{ }^{13} \mathrm{C}$ & $\% \mathrm{C}$ & $\begin{array}{l}\mathrm{CN} \\
\text { ratio }\end{array}$ & Element & Symmetry & $\begin{array}{l}\text { Find } \\
\text { number }\end{array}$ \\
\hline 42 & Mammal & $\begin{array}{l}\text { Oryctolagus } \\
\text { cuniculus }\end{array}$ & Rabbit & 9.2 & 13.2 & 14.5 & -14.5 & 41.5 & 3.3 & Humerus & Left & P.4.73 \\
\hline 30 & Mammal & $\begin{array}{l}\text { Ovis aries/Capra } \\
\text { hircus }\end{array}$ & Sheep/goat & 4.9 & 8.3 & 12.0 & -13.5 & 35.3 & 3.5 & Tibia & Left & 4.106 \\
\hline 31 & Mammal & $\begin{array}{l}\text { Ovis aries/Capra } \\
\text { hircus }\end{array}$ & Sheep/goat & 3.2 & 7.6 & 11.9 & -19.5 & 35.7 & 3.5 & Tibia & Left & 4.23 \\
\hline 33 & Mammal & $\begin{array}{l}\text { Ovis aries/Capra } \\
\quad \text { hircus }\end{array}$ & Sheep/goat & 13.3 & 10.6 & 14.9 & -16.0 & 41.9 & 3.3 & Tibia & Left & 4.4 \\
\hline 34 & Mammal & $\begin{array}{l}\text { Ovis aries/Capra } \\
\quad \text { hircus }\end{array}$ & Sheep/goat & 12.4 & 8.8 & 13.6 & -20.1 & 38.6 & 3.3 & Tibia & Left & 4.1 .78 \\
\hline 35 & Mammal & $\begin{array}{l}\text { Ovis aries/Capra } \\
\quad \text { hircus }\end{array}$ & Sheep/goat & 14.1 & 8.3 & 15.2 & -18.3 & 42.6 & 3.3 & Tibia & Left & 4.204 \\
\hline 36 & Mammal & $\begin{array}{l}\text { Ovis aries/Capra } \\
\quad \text { hircus }\end{array}$ & Sheep/goat & 18.3 & 9.4 & 12.7 & -14.1 & 35.9 & 3.3 & Tibia & Left & 4.21 \\
\hline 37 & Mammal & $\begin{array}{l}\text { Ovis aries/Capra } \\
\quad \text { hircus }\end{array}$ & Sheep/goat & 2.7 & 7.3 & 13.7 & -11.0 & 39.3 & 3.4 & Tibia & Left & 4.24 \\
\hline 38 & Mammal & $\begin{array}{l}\text { Ovis aries/Capra } \\
\quad \text { hircus }\end{array}$ & Sheep/goat & 5.6 & 7.2 & 11.9 & -13.3 & 33.9 & 3.3 & Tibia & Left & 4.43 \\
\hline 39 & Mammal & Sus domesticus & Pig & 2.1 & 10.2 & 11.4 & -18.8 & 35.1 & 3.6 & Humerus & TBS & 4.2 \\
\hline 40 & Mammal & Sus domesticus & Pig & 4.6 & 10.8 & 12.5 & -19.1 & 36.2 & 3.4 & Tibia & Left & 4.3 \\
\hline 50 & Mammal & Sus domesticus & Pig & 10.5 & 11.1 & 12.5 & --18.4 & 35.7 & 3.3 & Mandible & Right & $\mathrm{T} 23.4 .2$ \\
\hline \multirow[t]{5}{*}{43} & Pisces & Sparidae & Sea breams/porgies & 4.6 & 12.4 & 9.5 & -11.8 & 28.2 & 3.5 & Os dentale & - & - \\
\hline & \multirow[t]{2}{*}{ Pisces } & & Anchovy (ave.) & & 10.6 & & -11.0 & & & & & \\
\hline & & & $\mathrm{SD}$ & & 0.5 & & 0.6 & & & & & \\
\hline & \multirow[t]{2}{*}{ Pisces } & & Roundherring (ave.) & & 11.3 & & -11.6 & & & & & \\
\hline & & & SD & & 1.1 & & 0.9 & & & & & \\
\hline
\end{tabular}

The results of the quantitative analyses (model outputs) are listed in Table 6 and displayed in Fig. 4. Combining the model outputs for all individuals (sample population mean, $n=13$ ), land animals accounted for $17.2 \pm 13.1 \%$ of total dietary intake, marine animals accounted for $13.5 \pm 8.9 \%, \mathrm{C}_{3}$ plants for
$54.7 \pm 10.9 \%$ and $\mathrm{C}_{4}$ plants for $14.7 \pm 8.2 \%$. These dietary estimates, however, include several individuals who have been identified as non-locals based on strontium isotope analyses of dental enamel and/or M1 dentin $\delta^{13} \mathrm{C}$ values that are uncharacteristic of the assumed Cape enslaved diet, and thus,
Fig. 3 Cape of Good Hope archaeological faunal data and modern average \pm 1 SD anchovy and round herring data, together with the average \pm 1 SD isotope values for the Cobern Street (CS: Cox et al. 2001) and Marina Residence (MR: Mbeki et al. 2017) individuals

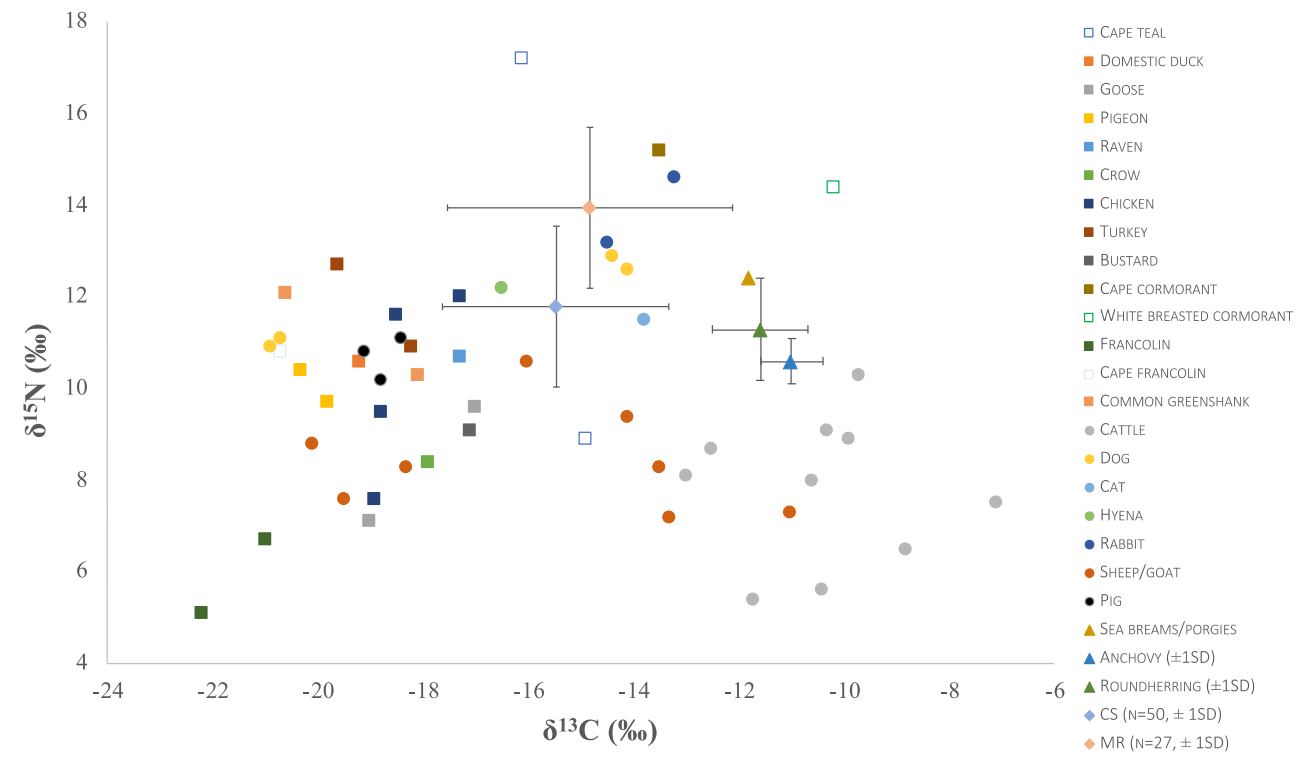


Table 5 Human stable isotope data from the Cape. $\delta^{13} \mathrm{C}$ is reported in per mil (\%o) versus VPDB. $\delta^{15} \mathrm{~N}$ is reported in per mil (\%o) versus AIR. Human $\delta^{13} \mathrm{C}_{\text {dentine }}$ and $\delta^{15} \mathrm{~N}_{\text {dentine }}$ data from Cox et al. (2001)

\begin{tabular}{|c|c|c|c|c|c|c|c|c|c|c|c|}
\hline $\begin{array}{l}\text { Burial } \\
\#\end{array}$ & $\begin{array}{l}\text { UCT } \\
\#\end{array}$ & Sex & $\begin{array}{l}\text { Age } \\
\text { (year) }\end{array}$ & $\begin{array}{l}\text { Dental element } \\
\text { (FDI) }\end{array}$ & $\delta^{13} \mathrm{C}_{\text {enamel }}$ & $\begin{array}{l}\text { Dental element } \\
\text { (FDI) }\end{array}$ & $\delta^{13} \mathrm{C}_{\text {dentine }}$ & $\delta^{15} \mathrm{~N}_{\text {dentine }}$ & $\begin{array}{l}\delta^{13} \mathrm{C}_{\text {whole }} \\
\text { diet }\end{array}$ & $\delta^{13} \mathrm{C}_{\text {protein }}$ & $\delta^{15} \mathrm{~N}_{\text {protein }}$ \\
\hline 18 & 508 & $\mathrm{~F}$ & $>50$ & 18 & -10.3 & 26 & -13.9 & 11.8 & -20.4 & -17.7 & 8.2 \\
\hline 23 & 516 & $\mathrm{~F}$ & $17-19$ & 38 & -10.0 & 36 & -15.3 & 12.0 & -20.1 & -19.7 & 8.4 \\
\hline 32 & 526 & $\mathrm{M}$ & $50-60$ & 48 & -12.0 & 46 & -18.0 & 11.4 & -22.1 & -22.2 & 7.8 \\
\hline $42 \mathrm{~A}$ & 539 & M & $40-50$ & 16 & -9.4 & 16 & -14.6 & 13.6 & -19.5 & -19.1 & 10.0 \\
\hline 47 & 545 & $\mathrm{M}$ & $30-40$ & 46 & -10.1 & 46 & -15.3 & 12.1 & -20.2 & -19.7 & 8.5 \\
\hline 61 & 559 & M & 35 & 46 & -11.0 & 46 & -15.5 & 14.6 & -21.1 & -19.4 & 11.0 \\
\hline \multicolumn{5}{|c|}{ Mean "local" population } & -10.5 & & -15.4 & 12.6 & -20.6 & -19.6 & 9.0 \\
\hline 14 & 502 & $\mathrm{~F}$ & $45-55$ & 48 & -11.5 & 46 & -19.2 & 8.8 & -21.6 & -24.1 & 5.2 \\
\hline 21 & 514 & $\mathrm{~F}$ & $25-35$ & 38 & -10.7 & 46 & -11.3 & 12.3 & -20.8 & -13.8 & 8.7 \\
\hline 34 & 528 & $\mathrm{~F}$ & $14-15$ & 46 & -13.4 & 46 & -19.8 & 10.3 & -23.5 & -23.9 & 6.7 \\
\hline 50 & 548 & M & $35-50$ & 48 & -3.0 & 46 & -9.8 & 7.6 & -13.1 & -16.3 & 4.0 \\
\hline 54 & 552 & M & $30-35$ & 48 & -12.5 & 46 & -18.6 & 9.9 & -22.6 & -22.8 & 6.3 \\
\hline 57 & 555 & $\mathrm{~F}$ & $20-30$ & 48 & -12.4 & 32 & -18.4 & 11.8 & -22.5 & -22.5 & 8.2 \\
\hline 58 & 556 & $\mathrm{~F}$ & $35-40$ & 18 & -9.2 & 36 & -11.9 & 11.7 & -19.3 & -15.5 & 8.1 \\
\hline \multicolumn{5}{|c|}{ Mean immigrant population } & -10.4 & & -15.6 & 10.3 & -20.5 & -19.8 & 6.7 \\
\hline \multicolumn{5}{|c|}{ Mean complete investigated population } & -10.4 & & -15.5 & 11.5 & -20.5 & -19.7 & 7.9 \\
\hline
\end{tabular}

not all of them clearly reflect colonial Cape diets. Removing these non-locals from the calculations, the typical local mean colonial Cape diets $(n=8)$ are based on land animals $16.0 \pm$ $12.5 \%$, marine animals $16.5 \pm 9.9 \%, \mathrm{C}_{3}$ plants $55.8 \pm 10.0 \%$ and $\mathrm{C}_{4}$ plants $11.7 \pm 7.9 \%$.
On average, $\mathrm{C}_{3}$ plants comprise the largest single dietary component representing the majority of overall intake, followed by marine and land animals, and $\mathrm{C}_{4}$ plants in descending order. It stands to reason that the $\mathrm{C}_{3}$ plant and $\mathrm{C}_{3}$ plant-consuming animals are the majority of the overall intake as consumption of a

Table 6 Individual model results. Non-local individuals have been excluded from some calculations (see text for explanation). Osteological data from Cox et al. (2001). SD: standard deviation

\begin{tabular}{|c|c|c|c|c|c|c|c|c|c|c|c|c|c|}
\hline \multirow[b]{2}{*}{ Burial \# } & \multirow[b]{2}{*}{ UCT \# } & \multirow[b]{2}{*}{ Sex } & \multirow[b]{2}{*}{ Age (year) } & \multicolumn{10}{|c|}{ Contribution per food group in percentage $(\%)$} \\
\hline & & & & Land & SD & Marine & $\mathrm{SD}$ & $\mathrm{C}_{3}$ & $\mathrm{SD}$ & $\mathrm{C}_{4}$ & SD & Animal & Vegetation \\
\hline 18 & 508 & $\mathrm{~F}$ & $>50$ & 16.0 & 11.5 & 19.5 & 13.7 & 50.3 & 8.9 & 14.2 & 9.2 & 35.5 & 64.5 \\
\hline 23 & 516 & $\mathrm{~F}$ & $17-19$ & 20.1 & 15.4 & 16.8 & 8.9 & 52.5 & 11.9 & 10.7 & 6.3 & 36.8 & 63.2 \\
\hline 32 & 526 & M & $50-60$ & 11.9 & 8.0 & 10.5 & 5.8 & 67.5 & 6.3 & 10.1 & 7.5 & 22.4 & 77.6 \\
\hline $42 \mathrm{~A}$ & 539 & M & $40-50$ & 15.5 & 12.9 & 20.7 & 12.4 & 49.9 & 9.4 & 13.9 & 9.8 & 36.2 & 63.8 \\
\hline 47 & 545 & M & $30-40$ & 14.8 & 9.4 & 14.8 & 9.1 & 58.7 & 10.3 & 11.8 & 7.8 & 29.5 & 70.5 \\
\hline 61 & 559 & M & 35 & 17.6 & 17.8 & 16.9 & 9.6 & 55.7 & 13.3 & 9.8 & 7.0 & 34.5 & 65.5 \\
\hline \multicolumn{4}{|c|}{ Mean "local" population } & 16.0 & 12.5 & 16.5 & 9.9 & 55.8 & 10.0 & 11.7 & 7.9 & 32.5 & 67.5 \\
\hline 14 & 502 & $\mathrm{~F}$ & $45-55$ & 21.9 & 21.0 & 9.2 & 7.2 & 57.4 & 19.3 & 11.5 & 7.2 & 31.0 & 69.0 \\
\hline 21 & 514 & F & $25-35$ & 26.8 & 18.3 & 17.4 & 10.7 & 41.7 & 14.3 & 14.1 & 9.4 & 44.2 & 55.8 \\
\hline 34 & 528 & $\mathrm{~F}$ & $14-15$ & 5.6 & 5.3 & 5.5 & 4.0 & 82.3 & 6.1 & 6.6 & 5.5 & 11.1 & 88.9 \\
\hline 50 & 548 & $\mathrm{M}$ & $35-50$ & 14.4 & 11.2 & 9.5 & 9.1 & 21.9 & 7.9 & 54.2 & 14.1 & 23.8 & 76.2 \\
\hline 54 & 552 & M & $30-35$ & 13.0 & 11.4 & 8.2 & 5.7 & 72.0 & 11.7 & 6.8 & 4.9 & 21.2 & 78.8 \\
\hline 57 & 555 & $\mathrm{~F}$ & $20-30$ & 13.3 & 11.6 & 9.5 & 6.9 & 69.2 & 9.6 & 8.0 & 6.3 & 22.8 & 77.2 \\
\hline 58 & 556 & F & $35-40$ & 32.3 & 16.1 & 16.8 & 12.2 & 31.5 & 13.2 & 19.4 & 11.8 & 49.1 & 50.9 \\
\hline \multicolumn{4}{|c|}{ Mean immigrant population } & 18.2 & 13.6 & 10.9 & 8.0 & 53.7 & 11.7 & 17.2 & 8.5 & 29.0 & 71.0 \\
\hline \multicolumn{4}{|c|}{ Mean complete investigated population } & 17.1 & 13.0 & 13.7 & 8.9 & 54.7 & 10.9 & 14.5 & 8.2 & 30.8 & 69.2 \\
\hline
\end{tabular}


Fig. 4 Individual mean modelled dietary contributions
Marine $n$ Land $\square$ C3 $\quad \mathrm{C} 4$

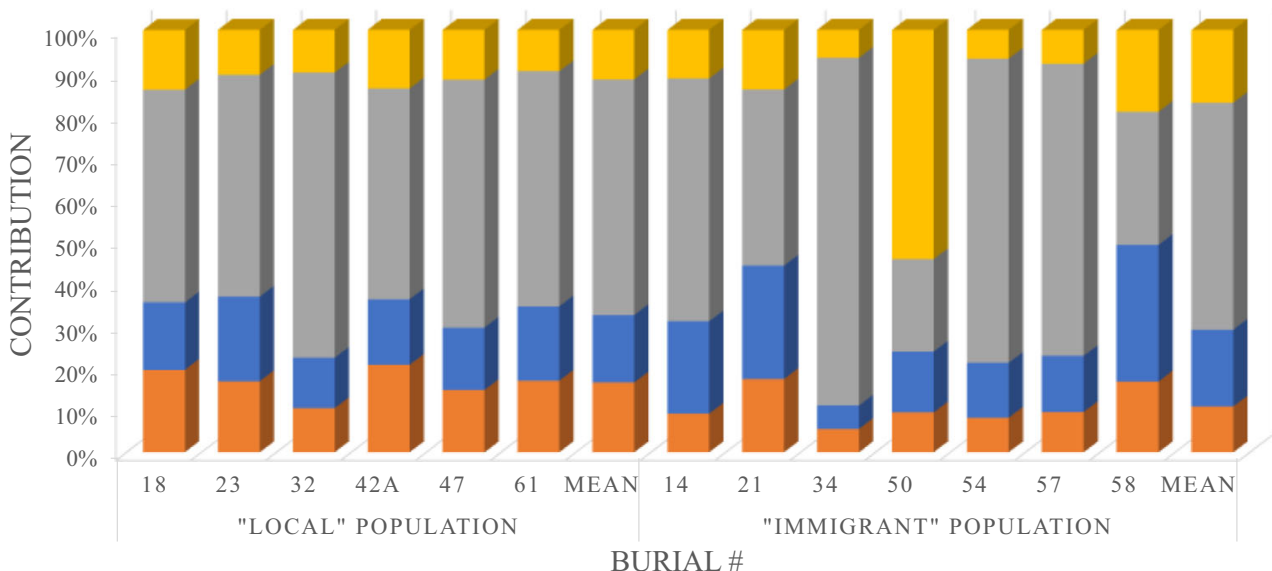

mainly $\mathrm{C}_{3}$ diet with some $\mathrm{C}_{4} /$ marine contribution was one of the criteria used to identify locals. Statistical assessments of simulated dietary contributions were made using Student's $t$ tests, assuming unequal variances (based on the results of associated $F$ tests). Owing to the possibility of overfitting with large sample sizes based on the 10,000 simulation runs of the FRUITS model, an alpha value of 0.01 was used for comparisons of differences in model outputs. Statistical tests of the model outputs for the trimmed dataset (excluding non-locals; $n=7$ ) for all four food source groups revealed significant differences for certain pairwise combinations. For example, the mean contribution of $\mathrm{C}_{3}$ plants was significantly higher than that of $\mathrm{C}_{4}$ plants $(t=$ 8.917, $d f=8, p<0.01$ ).

Nevertheless, substantial inter-individual variation was also observed even within the trimmed dataset with the calculated mean dietary contributions of land animals ranging from $11.9 \pm 8.0$ to $20.1 \pm 15.4 \%$, of marine animals from $10.5 \pm 5.8$ to $20.7 \pm 12.4 \%$, of $\mathrm{C}_{3}$ plants from $49.9 \pm 9.4$ to $67.5 \pm 6.3 \%$ and of $\mathrm{C}_{4}$ plants from $9.8 \pm 7.0$ to $14.2 \pm 9.2 \%$. A closer examination of the modelled outputs, however, indicates that much of the observed variation is represented by a few individuals that deviate significantly from the average values (outliers). For example, considering the relative proportions of land versus marine animals, only two individuals (18 and 42A) have an estimated marine input that is higher than the land input. Individual 42A, who was determined to have been an indigenous person buried before the arrival of the colonists, was included in the sample for comparison. Although this individual's total animal and plant dietary intake is comparable with that of the colonial individuals, she consumed the highest amount of marine protein $(20.7 \pm 12.4 \%)$.

Returning to the overall data set (including the non-local individuals), even more inter-individual variation in diets is observed. Combining the model outputs for land and marine animals into a single 'animal food' category, and the $\mathrm{C}_{3}$ and $\mathrm{C}_{4}$ plant food groups into a single 'plant food' category, it is clear that for all individuals, plant foods (mean $=69.4 \pm 13.7 \%$; range $=50.9$ to $88.9 \%)$ represented a larger dietary component than animal foods $($ mean $=30.6 \pm 15.8 \%$; range $=11.1$ to $49.1 \%)$.

The data presented here demonstrate significant variation in the circumstances, and therefore the diet, of the enslaved and the newly freed. The varied dietary reconstructions may be due to, for instance, an individual's network and the ability it afforded them to acquire specific foods. Some enslaved persons earned money (koelij geld) peddling goods for their masters and this relative freedom would have a significant effect on what foods were accessible to an individual.

\section{Conclusions}

This study has shed some light on animal husbandry practices at the Cape and its hinterland and provided the first dietary baseline for application to the delineation of the underclass diet at the colonial Cape. The isotopic data from the fauna demonstrate that herds of cattle were possibly grazed far inland in an arid $\mathrm{C}_{4}$ biome. A few sheep/goats have similar isotopic compositions suggesting they too were grazed far from the coast. Animals from the domestic sphere displayed elevated $\delta^{15} \mathrm{~N}$ values probably as a result of consumption of manured plants and/or a combination of coastal influences. These data have served mainly to exclude wild and domestic fowl, pork, beef and even marine fish as significant protein contributors to enslaved diets. Fowl were rare, and cattle were in short supply and probably reserved for provisioning passing ships and would not be set aside for enslaved persons. Mutton is a possible contributor to underclass diet which is in agreement with archaeological studies (Markell et al. 1995). There is still room to extend this baseline, particularly with fish isotopic data.

Where the qualitative approach allowed us to exclude possible protein sources, the quantitative reconstruction of diets using FRUITS gives a first insight into the proportions of terrestrial animals, marine animals, $\mathrm{C}_{3}$ plants and $\mathrm{C}_{4}$ plants 
that the enslaved individuals consumed. The data generated here are the first of their kind available for enslaved persons at the Cape. The data demonstrate that marine fish intake was limited amongst enslaved persons despite its abundance and affordability, a fact that is not evident from either the archaeological or historical records. The different circumstances of these individuals, which have previously been underestimated, are evident from their heterogeneous diets, an insight that is not evident from the VOC archive which only recorded the diet of Company-owned enslaved persons.

Supplementary Information The online version contains supplementary material available at https://doi.org/10.1007/s12520-020-01265-1.

Acknowledgements The authors would like to thank Prof. Alan Morris (University of Cape Town) for access to the Cobern Street collection. Heritage Western Cape is thanked for granting permission for sampling. South African Heritage Resources Agency is thanked for providing the sample export permit. The authors would further like to acknowledge Dr. Graham Avery for his assistance identifying the faunal material, Jan Bakker (University of Amsterdam) for identifying the archaeological fish specimen and Jaco Boshoff, Ethan Cottee and Gerty Thirion (IZIKO) for facilitating the sampling process. The raw modern fish data are kindly provided by Carl van der Lingen (University of Cape Town/ Department of Agriculture, Forestry and Fisheries, South Africa). We are indebted to Richard van Logtestijn, Vrije Universiteit Amsterdam, for the prompt production of $\mathrm{C}$ and $\mathrm{N}$ isotope data. Suzan Verdegaal and Remy van Baal, Vrije Universiteit Amsterdam, generated the $\delta^{13} C_{\text {apatite }}$ data. Bert Brouwenstijn is thanked for producing the map.

Authors' contributions Conceptualisation performed by LM and LMK. Analysis performed by LM. Visualisation by LMK and JEL. Manuscript preparation by JEL, LMK and LM. Supplementary data collection by LMK. FRUITS data generated by JEL. Supervision provided by GRD and $\mathrm{HK}$.

Funding LM was supported financially by the Oppenheimer Memorial Trust (OMT ref. 19671/02), the Van Ewijck Foundation and the National Research Foundation (NRF South Africa, grant no. 74691). GRD is funded by the European Research Council under the European Union's Seventh Framework Programme (FP7/2007-2013)/ERC Synergy grant (agreement no. 319209).

\section{Compliance with ethical standards}

Conflict of interest The authors declare that they have no conflict of interest.

Permits All necessary permits were obtained, which complied with all relevant regulations. Permission for sampling and analysis was granted by Heritage Western Cape (Case number: 16090209ASO929E) and an export permit for samples was obtained from the South African Heritage Resource Agency (Case ID: 10313. Permit ID: 2416).

Open Access This article is licensed under a Creative Commons Attribution 4.0 International License, which permits use, sharing, adaptation, distribution and reproduction in any medium or format, as long as you give appropriate credit to the original author(s) and the source, provide a link to the Creative Commons licence, and indicate if changes were made. The images or other third party material in this article are included in the article's Creative Commons licence, unless indicated otherwise in a credit line to the material. If material is not included in the article's Creative Commons licence and your intended use is not permitted by statutory regulation or exceeds the permitted use, you will need to obtain permission directly from the copyright holder. To view a copy of this licence, visit http://creativecommons.org/licenses/by/4.0/.

\section{References}

Ambrose SH (1990) Preparation and characterization of bone and tooth collagen for isotopic analysis. J Archaeol Sci 17:431-451. https:// doi.org/10.1016/0305-4403(90)90007-R

Ambrose SH (1991) Effects of diet, climate and physiology on nitrogen isotope abundances in terrestrial food webs. J Archaeol Sci 18:293317

Ambrose SH (2002) Controlled Diet and Climate Experiments on NitrogenIsotope Ratios of Rats. In: Ambrose S.H., Katzenberg M.A. (eds)Biogeochemical Approaches to Paleodietary Analysis. Advances inArchaeological and Museum Science, vol 5 (pp 243259). Springer, Boston.https://doi.org/10.1007/0-306-47194-9_12

Ambrose SH, DeNiro MJ (1986) The isotopic ecology of East African mammals Oecologia 69:395-406

Andrén A (1998) Between artefact and texts: historical archaeology in global perspective. Springer, New York

Armstrong JC (1979) The slaves. In: Elphick R, Giliomee H (eds) The shaping of South African society, 1652-1820. Longman, Cape Town, pp 5-115

Armstrong JC (2012) The Chinese exiles. In: Worden N (ed) Cape Town between east and west: social identities in a Dutch Colonial Town. Jacana Media, Pretoria

Baderoon G (2007) Catch with the eye: stories of Muslim food in Cape Town imagining the city: memories and cultures in Cape Town. HSRC Press, Cape Town

Bastos MQR, Santos RV, M. de Souza SMF, Rodrigues-Carvalho C, Tykot RH, Cook DC, Santos RV (2016) Isotopic study of geographic origins and diet of enslaved Africans buried in two Brazilian cemeteries J Archaeol Sci 70:82-90 https://doi.org/10.1016/j.jas. 2016.04.020

Bataille CP, von Holstein ICC, Laffoon JE, Willmes M, Liu X-M, Davies GR (2018) A bioavailable strontium isoscape for Western Europe: a machine learning approach PLOS ONE 13:e0197386 https://doi. org/10.1371/journal.pone.0197386

Bogaard A, Heaton THE, Poulton P, Merbach I (2007) The impact of manuring on nitrogen isotope ratios in cereals: archaeological implications for reconstruction of diet and crop management practices. $\mathrm{J}$ Archaeol Sci 34:335-343

Calvin M, Benson AA (1948) The path of carbon in photosynthesis Science 107:476-480

Copeland SR, Cawthra HC, Fisher EC, Lee-Thorp JA, Cowling RM, le Roux PJ, Hodgkins J, Marean CW (2016) Strontium isotope investigation of ungulate movement patterns on the Pleistocene PaleoAgulhas Plain of the Greater Cape Floristic Region. South Africa Quaternary Science Reviews 141:65-84. https://doi.org/10.1016/j. quascirev.2016.04.002

Cox G (1996) Historical background and isotopic analysis of skeletons found near the site of Fort Knokke Cape Town Foreshore, PhD thesis. University of Cape Town, Cape Town

Cox G, Sealy JC (1997) Investigating identity and life histories: isotopic analysis and historical documentation of slave skeletons found on the Cape Town foreshore, South Africa. International Journal of Historical Archaeology 1:207-224. https://doi.org/10.1023/A: 1027349115474

Cox G, Sealy J, Schrire C, Morris A (2001) Stable Carbon and Nitrogen Isotopic Analyses of the Underclass at the Colonial Cape of Good 
Hope in the Eighteenth and Nineteenth Centuries. World Archaeology 33:73-97. https://doi.org/10.2307/827890

De Kock V (1950) Those in bondage. George Allen \& Unwin LTD, London

DeNiro MJ, Epstein S (1981) Influence of diet on the distribution of nitrogen isotopes in animals. Geochimica et cosmochimica acta 45(3):341-351

Farquhar GD (1983) On the nature of carbon isotope discrimination in C4 species. Aust J Plant Physiol 10:205-226

Fernandes R, Nadeau M-J, Grootes PM (2012) Macronutrient-based model for dietary carbon routing in bone collagen and bioapatite. Archaeol Anthropol Sci 4:291-301. https://doi.org/10.1007/ s12520-012-0102-7

Fernandes R, Millard AR, Brabec M, Nadeau M-J, Grootes P (2014) Food reconstruction using isotopic transferred signals (FRUITS): a Bayesian model for diet reconstruction. PLOS ONE 9:e87436. https://doi.org/10.1371/journal.pone.0087436

Giovannetti PM (1982) Effect of coprophagy on nutrition. Nutr Res 2: 335-349

Goodman AH et al (2009) Isotopic and elemental chemistry of teeth: implications for places of birth, forced migration patterns, nutritional status, and pollution. In: Blakey ML, Rankin-Hill LM (eds) Skeletal biology of the New York African burial ground part 1. Howard University, Washington D.C., pp 95-118

Groenewald G (2010) Slaves and free blacks in VOC Cape Town, 16521795 history. Compass 8(9):964-983

Halkett D (1991) Report on archaeology excavations at the castle 18-29 November 1991. Archaeological Contracts Office (ACO), University of Cape Town

Hare PE, Fogel ML, Stafford TW Jr, Mitchell AD, Hoering TC (1991) The isotopic composition of carbon and nitrogen in individual amino acids isolated from modern and fossil proteins. J Archaeol Sci 18(3):277-292

Hatch MD, Slack CR (1966) Photosynthesis by sugarcane leaves. A new carboxylation reaction and the pathway of sugar formation. The Biochemical Journal 101:103-111

Hedges REM, Reynard LM (2007) Nitrogen isotopes and the trophic level of humans in archaeology. J Archaeol Sci 34:1240-1251. https://doi.org/10.1016/j.jas.2006.10.015

Heinrich AR (2010) A zooarchaeological investigation into the meat industry established at the Cape of Good Hope by the Dutch East IndiaCompany in the seventeenth and eighteenth centuries. Rutgers The State University of New Jersey-New Brunswick

Heinrich A, Schrire C (2011) Colonial Fauna at the Cape of Good Hope: a proxy for colonial impact on indigenous people. In: Schablitsky JM, Leone MP (eds) Historical archaeology and the importance of material things II. The Society for Historical Archaeology Special Publication Number 9, Rockville

Henning SS, Hoffman LC (2017) Proximate and fatty acid composition of cooked South African Cape snoek (Thyrsites atun). South African Journal of Science 113:1-4

Hobson KA, Alisauskas RT, Clark RG (1993) Stable nitrogen isotope enrichment in avian tissues due to fasting and nutritional stress: implications for isotopic analysis of diet Condor 95:388-394

Hodell DA, Quinn RL, Brenner M, Kamenoc G (2004) Spatial variation of strontium isotopes $\left({ }^{87} \mathrm{Sr} /{ }^{86} \mathrm{Sr}\right)$ in the Maya region: a tool for tracking ancient human migration. J Archaeol Sci 31:585-601

Howland MR, Corr LT, Young SM, Jones V, Jim S, Van Der Merwe NJ, Mitchell AD, Evershed RP (2003) Expression of the dietary isotope signal in the compound-specific $\delta 13 \mathrm{C}$ values of pig bone lipids and amino acids. Int J Osteoarchaeol 13(1-2):54-65

Keeling CD, Mook WG, Tans PP (1979) Recent trends in the 13C/12C ratio of atmospheric carbon dioxide. Nature 277:121-123. https:// doi.org/10.1038/277121a0
Kelly JF (2000) Stable isotopes of carbon and nitrogen in the study of avian and mammalian trophic ecology. Canadian J Zool 78:1-27. https://doi.org/10.1139/z99-165

Kootker LM, Mbeki L, Morris AG, Kars H, Davies GR (2016a) Dynamics of Indian Ocean slavery revealed through isotopic data from the colonial era Cobern street burial site, Cape Town, South Africa (1750-1827). PLoS ONE 11:e0157750. https://doi.org/10. 1371/journal.pone.0157750

Kootker LM, Van Lanen RJ, Kars H, Davies GR (2016b) Strontium isoscapes in the Netherlands. Spatial variations in ${ }^{87} \mathrm{Sr} /{ }^{86} \mathrm{Sr}$ as a proxy for palaeomobility J Archaeol Sci: Reports 6:1-13 https:// doi.org/10.1016/j.jasrep.2016.01.015

Laffoon JE, Davies GR, Hoogland MLP, Hofman CL (2012a) Spatial variation of biologically available strontium isotopes $\left({ }^{87} \mathrm{Sr} /{ }^{86} \mathrm{Sr}\right)$ in an archipelagic setting: a case study from the Caribbean. J Archaeol Sci 39:2371-2384

Laffoon JE, Valcárcel Rojas R, Hofman CL (2012b) Oxygen and carbon isotope analysis of human dental enamel from the Caribbean: implications for investigating individual origins. Archaeometry 55:742765

Laffoon JE, Espersen R, Mickleburgh HL (2018) The life history of an enslaved African: multiple isotope evidence for forced childhood migration from Africa to the Caribbean and associated dietary change Archaeometry 60:350-365 https://doi.org/10.1111/arcm. 12354

Lee-Thorp JA (2008) On isotopes and old bones. Archaeometry 50(6): 925-950

Lee-Thorp J, Sponheimer M (2003) Three case studies used to reassess the reliability of fossil bone and enamel isotope signals for paleodietary studies. J Anthropol Archaeol 22:208-216. https:// doi.org/10.1016/S0278-4165(03)00035-7

Leibbrandt HCV (1902) Precis of the archives of the Cape of Good Hope: Journal, vol 1676. W.A. Richards \& Sons, Government Printers, Cape Town, pp 1671-1674

Marino BD, McElroy MB (1991) Isotopic composition of atmospheric $\mathrm{CO} 2$ inferred from carbon in C4 plant cellulose Nature 349:127-131 https://doi.org/10.1038/349127a0

Markell A, Hall M, Schrire C (1995) The historical archaeology of Vergelegen, an early farmstead at the Cape of Good Hope. Hist Archaeol 29:10-34

Marshall JD, Brooks JR, Lajtha K (2008) Sources of variation in the stable isotopic composition of plants. In: Michener R, Lajtha $\mathrm{K}$ (eds) Stable isotopes in ecology and environmental science. Blackwell Publishing Ltd, Malden, pp 22-60. https://doi.org/10. 1002/9780470691854.ch2

Mbeki L, Kootker LM, Kars H, Davies GR (2017) Sickly slaves, soldiers and sailors. Contextualising the Cape's 18 th-19th century green point burials through isotope investigation J Archaeol Sci: Reports 11:480-490 https://doi.org/10.1016/j.jasrep.2016.12.026

Moenieba I (2013) Small-scale fisheries governance and understanding the Snoek (Thyrsites atun) supply chain in the ocean view fishing community. Western Cape, South Africa Ecology and Society 18:17

Moore JW, Semmens BX (2008) Incorporating uncertainty and prior information into stable isotope mixing models Ecology Letters 11: 470-480 https://doi.org/10.1111/j.1461-0248.2008.01163.x

Morrison DJ, Dodson B, Slater C, Preston T (2000) 13C natural abundance in the British diet: implications for $13 \mathrm{C}$ breath tests. Rapid Communications in Mass Spectrometry 14:1321-1324. https://doi. org/10.1002/1097-0231(20000815)14:15<1321::AID-RCM946>3. $0 . \mathrm{CO} ; 2-8$

Müldner G, Britton K, Ervynck A (2014) Inferring animal husbandry strategies in coastal zones through stable isotope analysis: new evidence from the Flemish coastal plain (Belgium, 1st-15th century AD). J Archaeol Sci 41:322-332

Nelson SJ, Ash MM (2010) Wheeler's dental anatomy, physiology, and occlusion (9th edition). Saunders Elsevier, St. Louis 
Newsome SD, Phillips DL, Culleton BJ, Guilderson TP, Koch PL (2004) Dietary reconstruction of an early to middle Holocene human population from the Central California coast: insights from advanced stable isotope mixing models. J Archaeol Sci 31:1101-1115. https:// doi.org/10.1016/j.jas.2004.02.001

Nystrom KC, Amato LA, Jankowitz LA (2011) Strontium isotopic reconstruction of the composition of an urban free black population from the $19^{\text {th }}$ century United States. J Archaeol Sci 38:3505-3517

O'Connell TC, Kneale CJ, Tasevska N, GGC K (2012) The diet-body offset in human nitrogen isotopic values: a controlled dietary study. Am J Phys Anthropol 149:426-434. https://doi.org/10.1002/ajpa. 22140

Parnell AC, Inger R, Bearhop S, Jackson AL (2010) Source partitioning using stable isotopes: coping with too much variation. PLOS ONE 5:e9672. https://doi.org/10.1371/journal.pone.0009672

Parnell AC et al (2013) Bayesian stable isotope mixing models. Environmetrics 24:387-399. https://doi.org/10.1002/env.2221

Pestle WJ (2010) Diet and society in prehistoric Puerto Rico an isotopic approach. $\mathrm{PhD}$ thesis, University of Illinois at Chicago

Pestle WJ, Colvard M (2012) Bone collagen preservation in the tropics: a case study from ancient Puerto Rico. J Archaeol Sci 39:2079-2090. https://doi.org/10.1016/j.jas.2012.03.008

Pestle WJ, Laffoon J (2018) Quantitative paleodietary reconstruction with complex foodwebs: an isotopic case study from the Caribbean Journal of Archaeological Science: Reports 17:393-403 https:// doi.org/10.1016/j.jasrep.2017.11.032

Pestle WJ, Crowley BE, Weirauch MT (2014) Quantifying interlaboratory variability in stable isotope analysis of ancient skeletal remains. PLOS ONE 9:e102844. https://doi.org/10.1371/journal. pone. 0102844

Pestle WJ, Hubbe M, Smith EK, Stevenson JM (2015) A linear model for predicting 813 Cprotein. Am J Phys Anthropol 157(4):694-703

Phillips DL (2001) Mixing models in analyses of diet using multiple stable isotopes: a critique. Oecologia 127:166-170

Phillips DL, Gregg JW (2003) Source partitioning using stable isotopes: coping with too many sources. Oecologia 136:261-269. https://doi. org/10.1007/s00442-003-1218-3

Preiser JC, Ichai C, Orban JC, ABJ G (2014) Metabolic response to the stress of critical illness. British Journal of Anaesthesia 113:945-954. https://doi.org/10.1093/bja/aeu187

Ross R (1983) Cape of torments: slavery and resistance in South Africa. Routledge, London

Schoeninger MJ, DeNiro MJ (1984) Nitrogen and carbon isotopic composition of bone collagen from marine and terrestrial animals. Geochimica et Cosmochimica Acta 48:625-639

Schoeninger MJ, Moore K (1992) Bone stable isotope studies in archaeology. Journal of World Prehistory 6:247-296
Schroeder H, O'Connell TC, Evans JA, Shule KA, REM H (2009) TransAtlantic slavery: isotopic evidence for forced migrations. Am J Phys Anthropol 139:547-557

Schroeder H, Haviser JB, Price TD (2014) The Zoutsteeg three: three new cases of African types of dental modification from Saint Martin, Dutch Caribbean. Intern J Osteoarchaeol 24(6):688-696. https:// doi.org/10.1002/oa.2253

Schwarcz HP, Schoeninger M (2011) Stable isotopes of carbon and nitrogen as tracers for paleo-diet reconstruction. In Handbook of environmental isotope geochemistry (pp. 725-742). Springer, Berlin, Heidelberg

Sholto-Douglas AD, Field JG, James AG, van der Merwe NJ (1991) ${ }^{13} \mathrm{C} /{ }^{12} \mathrm{C}$ and ${ }^{15} \mathrm{~N} /{ }^{14} \mathrm{~N}$ isotoperatios in the southern Benguela ecosystem: indicators of food web relationships among different sizeclasses of plankton and pelagic fish; differences between fish muscle and bone collagen tissues. Mar Ecol Prog Ser 78:23-31

Sponheimer M, Robinson T, Ayliffe L, Roeder B, Hammer J, Passey B, Ehleringer J (2003) Nitrogen isotopes in mammalian herbivores: hair $\delta 15 \mathrm{~N}$ values from a controlled feeding study. Int $\mathrm{J}$ Osteoarchaeol 13(1-2):80-87

Tieszen L (1991) Natural variations in the carbon isotope values of plants: implications for archaeology, ecology, and paleoecology. J Archaeol Sci 18:227-248

Unknown (1996) Phase 1 archaeological investigation of two areas of the castle moat. Archaeology Contracts Office, University of Cape Town

Unknown (1999a) An archaeological investigation of the basement rooms in B block: the castle. Archaeological Contracts Office (ACO), University of Cape Town

Unknown (1999b) An archaeological investigation of the Kat balcony: the castle. Archaeology Contracts Office (ACO), University of Cape Town

USDA (2013) United States Department of Agriculture - National Nutrient Database for Standard Reference, Release 26. Available at: https://www.ars.usda.gov/Services/docs.htm?docid=8964

Warinner C, Tuross N (2009) Alkaline cooking and stable isotope tissuediet spacing in swine: archaeological implications. J Archaeol Sci 36(8):1690-1697

van Groenigen JW, Kessel C (2002) Salinity-induced patterns of natural abundance carbon-13 and nitrogen- 15 in plant and soil. Soil Sci Soc Am J 66(2):489-498

WHO (2007) Protein and Amino Acid Requirements in Human Nutrition, vol 935. WHO Press, Geneva

Worden N (1985) Slavery in Dutch South Africa. Cambridge University Press, Cambridge

Publisher's note Springer Nature remains neutral with regard to jurisdictional claims in published maps and institutional affiliations. 